\title{
Devlete Güven ve Vergi Ahlakı İlişkisinin İbn Haldun'un İktisadi Düşünceleri Çerçevesinde İncelenmesi: Kırgızistan Örneği
}

\section{Investigation of the Relation between Trust to Government and Tax Morale in the Context of Ibn Khaldun's Economic Thoughts: The Case of Kyrgyzstan}

\author{
Razia Abdieva \\ Kırgızistan-Türkiye Manas Üniversitesi, Kırgızistan \\ razia.abdieva@manas.edu.kg
}

Geliş Tarihi: 20 Kasım 2021

Kabul Tarihi: 25 Ocak 2022

Yayın Tarihi: 30 Ocak 2022

Öz: Devletin en önemli gelir kaynağı vergilerdir. Son yıllarda iktisatçılar insanların vergi ödeme nedenlerine ve yaklaşılmalarına odaklanmışlardır. Yapılan ampirik çalışmalar kişilerin vergileri ödeme isteğine sadece vergi oranları, denetleme olasılığı ve vergi cezaları gibi iktisadi faktörler değil mükellefin yaşı, medeni durumu, dindarlık ve eğitim seviyesi, ekonomik statüsü gibi sosyo-demografik faktörler ile hükümete ve parlamentoya güven, kamu hizmetlerinin kalitesinden memnun olma gibi siyasi etkenler kişilerin vergi ile ilgili bakış açısı ve vergi davranışına ve sonuç olarak vergi ahlakı seviyesi üzerinde önemli etkide bulunmaktadır. Çalışmada Kırgızistan'da vergi ahlakının seviyesi ve siyasi faktörlerin vergi ahlakı üzerindeki etkisi 2010 ve 2013 yıllar arasında yapılan Dünya Değerler Anketi (World Values Survey) verilerini kullanarak incelenecektir. Bu araştırma kapsamında Kırgızistan'da 1500 anket gerçekleştirilmiştir. Söz konusu faktörleri incelemek için sıralı probit modeli uygulanacaktır. Çalışma sonucunda devlete olan güvenin ve vergi ahlakının arttırılması için verilecek önerilerde İbn Haldun'un düşüncelerinden faydalanılacaktır.

Anahtar Kelimeler: Vergi, Vergi Ahlakı, Devlete Güven, Asabiyet, Kırgızistan

Abstract: Tax revenues are significant in the economic and social development of the state. In recent years, economists have focused on the reasons why people pay taxes. One of the main causes of voluntarily paying taxes is tax morale of taxpayers. Empirical studies revealed that along with sociodemographic, socio-psychologic, economic factors, institutional factors too affect tax behavior. The aim of this paper is to investigate institutional factors such as trust to government, parliament, judiciary and legislative system to tax morale in Kyrgyzstan using World Values Survey data that conducted in 2011 to 1500 respondents. According to the results trust to officials of public sector, level of the protection of human rights and trust to election system has significant effect on tax morale in Kyrgyzstan.

Keywords: Taxes, Tax Morale, Trust in Government, Asabiyet, Kyrgyzstan

ORC-ID: R. Abdieva 0000-0002-9438-1558 


\section{Giriş}

İbn Haldun (1332-1406) Orta Çağ'ın öncü Arap-i̇slam düşünürlerindendir. Tarih, sosyoloji, siyaset bilimi, ekonomi, kamu yönetimi ve maliye alanlarında geleceğe yönelik, öncü ve kurama dönüşebilecek düşüncelerini bırakmıştır. İbn Haldun tarihi olaylara bilimsel yönden bakan, ilk defa eleştirerek analiz eden ve onların arkasındaki gerçekleri derin inceleyerek "neden-sonuç" ilişkisini kurmaya çalışan aydın bilim adamıdır.

İbn Haldun'un tüm adı geçen alanlardaki düşünceleri Mukaddime isimli eserinde yazılmıştır. Bu eserinde toplumların ortaya çıkış nedenleri, toplumların biçimi ve yapısı belirtilmiştir. Bunun dışında söz konusu eserde toplumun devleti oluşturma nedenleri, devletin gelişmesinin aşamaları, toplumun davranışı, kamu yönetimi ve yöneticilerin davranışını etkileyen faktörler hakkında teoriye dönüşmeye değer olan bilgileri bırakmıştır. Hatta bu eser sonraki sosyal bilimler alanındaki çok sayıdaki teorilerin gelişmesinde ilham kaynağı olduğu tahmin edilebilir.

Çalışmamızda Kırgızistan'da mükelleflerin devlete olan güveni ile vergi ahlakı derecesi arasındaki ilişki Dünya Değerler Örgütünün 6. sayısındaki veriler kullanılarak analiz edilmiştir. Girişi izleyen 2. bölümde İbn Haldun'un devlet ile ilgili görüşleri, 3. vergi Ahlakı ve Vergi Ahlakını etkileyen faktörler incelenmiştir, 4. bölümde veri ve yöntem anlatılmıştır ve 5 . bölümde de sonuç ve öneriler sunulmuştur.

\section{2. İbn Haldun'un Devlet İle İlgili Görüşleri}

İbn Haldun Mukaddime eserinde kişilerin sosyal varlık olduğuna işaret etmiştir. Toplumsal yaşam kaçınılmaz bir gerekliliktir. Çünkü insan sosyal varlıktır. (Mukaddime, 79. sayfa; çev. Kendir: 2004). İnsanın sosyal varlık olması onun kişisel ihtiyaçların dışında sosyal veya kamusal ihtiyaçlarının da var olduğunu bildirir. Kamusal ihtiyaçlarının en temeli ise iç ve dış güvenliktir. "Devlet olmanın gerektirdiği sonuçlardan biri de sükunet ve rahatlıktır" (Mukaddime, 239. sayfa çev. Kendir). Kişilerin rahat ve refah bir yaşam tercih etmeleri onları bir devlet kurmaya çabalamasına neden olmaktadır. Bununla birlikte kişiler egemenliğe sahip olmak için de topluma dönüşmeyi ve devlet olmayı istemektedirler. "Başkalarını yenip onlar üzerinde hakimiyetlerini kurmak ve kendilerine savunmak için sahip oldukları emel ve ortaya koydukları gayret ve cesaret gerçekten örnek bir boyuttadır. Devletlerini kurmak için seve seve canlarını verir ve devlet kurmakla kazanacakları yücelik ve üstünlüğü kaybetmektense ölmeyi tercih ederler" (Mukaddime, 238. Sayfa, çev. Kendir). 
İbn Haldun devletin kurulmasında en önemli unsurun asabiyet olduğunu söylemiştir. Asabiyet devletin kurulmasından sonra da devletin hayatta kalabilmesi ve faaliyet sürdürebilmesi için önemlidir. Asabiyet diğer bir değişle devlet için insanın ruhu gibi önemli olduğu söylenebilir.

Asabiyet düşmanlık saldırısından korunma ve üstün gelme amacıyla ancak nesep, kardeşlik ve akrabalık vasıtasıyla elde edildiğine işaret etmiştir. Asabiyet toplumsal güç ve taban (Mukaddime, sayfa 275) olduğunu, diğer bir değişle toplumun manevi ve sayı açısından da çok olması sayısal gücünü de ifade etmektedir. Farklı araştırmacılar tarafından "yakınlık bağı", "topluluk duygusu", "dayanışma duygusu", "ortak ruh", "toplumsal uyuşma", "toplumsal dayanışma", "milliyetçilik fikri", "askerî ruh" olarak tanımlanmıştır (Hassan, 1999).

Günümüzde ülkedeki ideoloji, halkın devleti desteklemesi ve devlet ile ilgili görüşü genel olarak aldığımızda halkın devlete güveni asabiyeti temsil edebilir. Çünkü halk ancak devlete güveni yüksek olduğunda onu destekler. İbn Haldun da asabiyetsiz devlet yönetimi zor veya imkansız olduğunu belirtmiştir. Asabiyetten bir hükümdarlığın (devletin) doğması isteğe bağlı bir şey değil, daha önce de söylediğimiz gibi, zorunlu bir durumdur. "Bil ki, hükümdarlık, asabiyetin tabii bir gayesi ve sonucudur. Şeriatlar, dinler ve bunlar gibi halkın (büyük kalabalıkların) yönlendirileceği her şey mutlaka asabiyet (birbirine kenetlenmiş toplumsal gü̧̈) gerekir." (Mukkaddime, 287, çev. Kendir). Devlet de halkın güvenine sahip olduğunda devleti etkin yönetebilir ve uyguladığı politikalarında da başarılı olacaktır.

İbn Haldun Mukaddime'de devleti canlı bir varlık olarak onun yaşam süresinin var olduğunu ve gelişme dönemlerini belirtmiştir. Devletin yaşama sürecini kuruluş, büyüme, olgunlaşma ve çökme aşamalarını belirtmiştir. Bu aşamalar: Kuruluş Dönemi, Otorite Dönemi, Refah Dönemi, Taklit dönemi ve Savurganlık Dönemi olarak beş dönemeye ayırmıştır.

1) Kuruluş Dönemi: Bu dönemde belli bir kabileyi galip ederek devleti kuracaktır ve topluluktan topluma dönüşme aşamasıdır. Bu aşamada asabiyet oldukça güçlüdür ve hükümdar henüz kendisini vatandaşlarından ayrı tutmaz. 'Bil ki, devletler başlangıçta (lüks, ihtişam ve görkem gibi) hükümdarlık eğilimlerinden uzak olurlar. Çünkü başlangıçta devletin kurulmasını ve hakimiyetini sağlayan bir asabiyetin olması şarttır. Başlangıçta devlet bu hal üzere olduğu gibi, devlet başkanı da sade, bedevi özellikte, insanlara yakın ve kendisine ulaşılması kolay biridir' (Mukaddime, sayfa 385). 'Devletler başlangıçta halkına karşı şefkat ve 
iyilikle muamele ederler. Eğer yönetim halka karşı yumuşak ve şefkatli olursa, insanların (geleceğe ilişkin) emelleri ve beklentileri canlanır, ülkenin imarını ve kalkınmasını sağlayacak sebeplere sarılıp çalışırlar ve toplumun nüfusu da artar (Mukaddime, sayfa 402). Bu dönemde hükümdar iktidara yeni geldiğinden halkına hizmet etmek ve otorite kazanma, itaate sahip olmak amacıyla ekonomik ve sosyal gelişmeyi sağlamaya gayret gösterecektir.

2) Otorite Dönemi: Bu aşamada iktidarı elinde bulunduran hükümdar kendi grubu üzerinde otoritesini tesis eder, mülkü ve nimetlerini kendisi için istemeye baslar. Grupta rakip olacak ileri gelenler yönetimden uzaklaştıııır, kendine bağlı itaatkar kişiler yönetime gelir. Ancak devlet başkanı iktidarını sağlamlaştırıp yönetimi tek başına ele alınca, işlerini, yakın çevresi ve seçkin adamlarıyla görüşme ihtiyacı duyar ve gücü yettiği kadar kendisini halktan soyutlar. (Mukaddime, sayfa 385). Bu dönemde iktidarda olmanın tüm faydalarını anladıktan sonra mümkün olduğu kadar iktidarda uzun süre kalmayı isteyerek buna tehdit eden faktörleri yok etmeye çalışır. Çünkü iktidarda olmanın lüks hayata alışmışır. Böylece bu dönemde iktidar devlet harcamasının artmasına neden olacaktır.

3) Refah Dönemi: Bu dönem devletin en gelişmiş dönemidir. Ekonomik refahın arttığı ve buna paralel olarak kültürel unsurların geliştiği dönemdir. Güçlü ordu ve yöneticilere sahip olan ve vergi gelirlerinin de düzenlidir. Bu dönemde iktidar lüks alışkanlıklarını daha da geliştirerek san ve şöhret ön plana çıkar ve kendini ölümsüzleştirecek eserler meydana getirilir. Bununla birlikte servetini arttırır.

İbn Haldun devletin gelişmesi ile kişilerin kamusal hizmetlere olan talebinin de arttığına işaret etmiştir. 'Toplumun devlet kurduktan sonra mal ve zenginliklerinin artması ile zorunlu ihtiyaçları karşılama derecesini aşıp, daha ince ve estetik ihtiyaçlarını karşılama imkanlarına kavuşur. Güzel binalar ve saraylar inşa etmek, oralara su akıtmak, bahçeler oluşturmak, en güzel yemekleri yemek, en güzel giyecekleri giymek, konutlarını en güzel şekilde döşemek ve en güzel kapları kullanmak gibi...' (Mukaddime, 237. Sayfa, çev. Kendir). Burada Wagner Kanunu olarak belli olan Kamu Harcamalarının Artış Kanunu ile ilgili görüşün var olduğunu söyleyebiliriz. Kişilerin geliri arttıkça onların kamusal mal ve hizmetlere olan talebi kamu harcamalarının hızından daha da yüksek hızda artacaktır. Bu kanun özellikle İbn Haldun da belirttiği gibi devletin ekonomik ve sosyal yönden gelişme aşamasında geçerlidir.

Bu aşamada devlet yönetiminde bozulma başladığını İbn Haldun şöyle belirtmiştir: 'Devlet güçlenip hükümdarlık aşamasına geldiğinde, hükümdar, iktidarda kendisine ortak olanları yönetimden uzaklaştırıp, iktidarı kendi tekeline almaya çalışır. Bunun için de işe, devlet yönetiminde diğerlerine göre daha etkili konumda olan kendi yakınlarından 
ve aşiretinden başlar. Yine hükümdarın yakınları sahip oldukları güç ve üstünlükten dolayı, diğerlerine göre daha fazla lüks ve bolluğa gömülmüşlerdir. Dolayısıyla hükümdarın kendi yakınları ve aşireti, iki yıkııı tehlike tarafından kuşatılmışlardır. Birincisi içine gömüldükleri lüks ve bolluk, ikincisi hükümdar tarafından gelecek olan darbe, yani yönetimden uzaklaştırılmaktır' (Mukaddime I, 391).

1) Taklit Dönemi: Bu dönemde siyasi iktidar, önceki yönetimden bırakılan sistemi yeterli görmeye baslar ve değişikliğe, yeniliğe karşılık gösterir. Sistemi koruma ve bu yolu takip etmek en doğru olduğuna inanır.

2) Savurganlık Dönemi: Siyasi iktidar, atalarından kalan mirası arzu ve hevesine göre israf etmeye ve savurganlık yapmaya baslar. Devlet yönetimine ehliyetsiz kişiler geçirilir. Devletin çözülme ve yıkılma sureci baslar. Ordusunu, memurunu besleyemez ve giderlerini karşılayamaz hale gelir ve yıkılır.

Devletin çöküşünün diğer bir nedeni ise hükümdarın etki altına alınıp işlevsiz hale gelmesidir. Hükümdarın çevresindekilerin etkisi altında kalması ve gerçeği görememesi devletin yıkılma dönemine geldiğinin belirtisidir. Fakat bu aşamada da hükümdar yönetiminin etkinliğini yükselterek devleti kurtarabilecektir. Ama 'devlet adamlarının sahip olukları lüks ve alışkanlıklar, bu durumdan kurtulmaya engeldir. Alışkanlıklar ise (değiştirilmesi mümkün olmayan) ayrı bir tabii durumdur. Örneğin, atalarının ve ev halkının ipek giydiğini, altından yapılmış silahlar kuşandığını, altından yapılmış binit takımları kullandığını, namazlarda ve meclislerde insanlardan soyutlanıp onlar arasına karışmadığını görerek yetişmiş birinin bütün bu hususlarda, kendisinden öncekilere aykırı davranarak kaba giysiler giyip insanlar arasına karışması mümkün değildir. Çünkü alışkanlıklar onun böyle yapmasını engeller ve bunu ona çirkin gösterir.' (Mukaddime I, 386-389).

Mali yönden bakıldığında da ilk dönemlerde 'devlet bedevi özelliklere sahip olduğu için, halka karşı şefkatli, harcamalarda ölçülü, haksız yere halkın malını yemekten uzak, çok vergi toplama amacı gütmeyen, tacirlerin her alış verişinden vergi almaktan kaçınan ve vergi memurlarından ayrıntılı hesaplar istemekten uzak bir yapıdadır. Dolayısıyla bu dönemde, harcamalarda aşırıya gitmeye gerektirecek sebepler ve buna bağlı olarak çok fazla paraya da ihtiyaç duyulmaz'(Mukaddime I, 393).

Sonraki dönemlerde idarecilerin lüks ve şenlere alışmaları kamu harcamalarının sürekli artışına neden olur. Bu ise kamu personeli ve askerlerin maaşların artmasını, bu da vergilerin arttırılmasını ortaya çıkarır. Vergi yükü dayanılmaz hale geldiğinde 
ekonominin gücü ve buna bağlı olarak da devletin gücü zayıflayarak devlet yıkılmaktadır (Mukaddime I, 393).

İbn Haldun devletin iki olmazsa olmaz temelinin askeri kuvvetler ve asabiyet gücü, ikincisi de devletin ihtiyaçlarım gideren mal ve paradır veya üretim gücüdür (Mukaddime I, 391). Böylece devletin gücünü ekonominin ve asabiyetin gücü bildirmektedir. Devlet kurulduktan sonraki aşamada asabiyet en yüksektir ve hükümdar da kişiler de istikrarlı ekonomiyi oluşturarak refaha ulaşmaya çaba gösterirler. Sonraki aşamalarda hükümdarın lükse alışması ve toplumdan uzaklaşarak işlevsiz hale gelmeye başlaması ile devletin yıkılmasına neden olmaktadır. Diğer bir değişle, hükümdarın davranışları, tercih ve arzuları, lükse bağlı olarak alışkanlıkları bunun adaletli hükümdardan işlevsiz iktidara dönüştürmektedir.

İbn Haldun etkin yönetimin iki çeşidini belirtmiştir. Bunlar akli siyaset ve İslam'a dayanan siyasettir. Akli siyasette asıl amaç hükümdarın daha uzun iktidarda kalması için iki yöntemle yönetilir: kendi çıkarları ve halkın da çıkarlarını hesaba katarak yönetmek ve ikincisi baskı ve zülüm ile yönetmek. Günümüzdeki kamu yönetimi de bireycilik ve rasyonellik ilkelerine dayanmaktadır. Bu da hükümdarın kendi çıkarlarına göre idare etmesine neden olmaktadır.

Fakat, İbn Haldun Müslüman toplumlarda İslam dinin ilkelerine göre, ahlaki kurallar ve asabiyetle ilgili zorunlu olarak dikkate alınması gereken hususlar temelinde yönetilmesi en etkin ve adaletli yönetim olduğunu bildirmektedir. Diğer bir değişle, iktidar sahibinin Allah korkusu ve sevgisine dayanarak iyi yönetime odaklanması ve bu dünyanın rahatlık ve lükslerine değil ahiretini düşünerek adaletli yönetmesidir. Bu bilinç ve anlayışa sahip olan idarecilerde yolsuzluk ve yetkisini kötüye kullanma gibi adaletsizlikler yok olacaktır. Fakat aynı zamanda kamu sektöründe çalışanların ekonomik yönden bağımsız olması için yeterli gelirle temin edilmesi gerekir.

Gelişmekte olan ülkelerde toplumun ekonomik ve sosyal gelişmesinin önündeki en önemli engel yolsuzluktur. Geçiş ekonomili genç bir devlet olan Kırgızistan'da da toplumun gelişmesini, yaşam memnuniyeti ve kalitesini azaltan etken olarak kamu yönetiminin etkin olmamasıdır. İbn Haldun'un devlet idarecilerinin İslam ilkeleri ve bilincine sahip olarak bu kurallara göre yönetmeleri halkın devlete olan güvenini de yükseltecekti ve ekonomik büyümenin de hızlanmasına neden olacaktı. Çünkü yolsuzluk sorunun damarı ekonomikten daha çok ahlaki bir sorundur. 


\section{Vergi Ahlakı ve Devlete Güven}

Vergiler devletin temel kaynağıdır. Dolayısıyla devletin etkin ve başarılı olabilmesinde vergi gelirlerin önemi büyüktür. Son yıllarda iktisatçılar kişilerin vergiye olan tutum ve davranışları, vergi bilinçleri ve vergi ahlakını incelemeye daha önem vermekteydiler. Çünkü vergileme iki taraflıdır. Vergi politikasının etkinliği ve başarısı mükelleflerin vergisel yükümlülüklerini ne kadar tam ve doğru yerine getirme isteklerine bağlıdır. Bunun dışında son 20-30 yılda yapılan ampirik çalışmalar vergi yükümlülüklerini yerine getirme mükellefler arasında klasik caydırıcı modelin tahmin ettiği seviyeden daha yüksek olduğu açıklanmıştır (Graetz ve Wilde, 1985; Alm, McClelland ve Schulze, 1992; Frey ve Feld, 2002).

Çoğu araştırmacılar bu bulmacanın anahtarı vergi kültürü olduğunu bildirmişlerdir (Alm, McClelland and Schulze, 1992, 1999; Pommerehne, Hart and Frey, 1994; Frey, 2003; Frey and Feld, 2002; Feld and Tyran, 2002; Torgler, 2001). Diğer bir değişle, kişiler cezalandırma ve yakalanma ihtimaline göre değil vergisel yükümlülükleri tam ve doğru olarak yerine getirme isteğine bağlı olarak vergileri ödediklerini bildirmişlerdir.

Vergi ahlakı vergileri ödemeye veya vergisel yükümlülükleri yerine getirmeye yönelik içsel motivasyon olarak tanımlanmaktadır (Torgler, 2003). Vergi ahlakı vergileri ödeme isteğidir. Diğer bir değişle, vergi ödemekle ilgili ahlaki zorunluluktur (Frey ve Torgler, 2004:7). Song ve Yarbrough'a (1978:443) göre 'vatandaşların mükellef olarak devlet ile ilişkilerinde yöneten davranış normlarıdır'. Schmölders (1976:111) ise vergi ahlakını 'vergi ile ilgili yükümlülük ve görevleri zamanında ve hatasız yerine getirme' olduğunu bildirir. Böylece, vatandaşların vergi ile ilgili görevlerini tam, doğru ve zamanında yerine getirme isteği ve içgüdüsü vergi ahlakı olmaktadır.

Vergi ahlakının yüksek olması devletin vergi yönetimi ile ilgili harcamaların azalmasına neden olacaktır. Vergi bilinci yüksek olan kişilerin çok olması da ülkede kamu harcamalarının savurganlığının azalmasına, vergi sisteminin daha adaletli ve etkin olmasında önemli rol oynamaktadırlar. Dolayısıyla vergi ahlakını etkileyen faktörler daha çok ele alınmaktadır. Yapılan ampirik çalışmaların sonuçlarına göre vergi ahlakını etkileyen faktörleri dörde ayırabiliriz. Bunlar sosyo-demografik, ekonomik, sosyopsikolojik ve siyasal faktörlerdir.

Sosyo-psikolojik faktörlere vergi algılaması, vergi bilinci, vergi psikolojisi, vergiye ilişkin tutum ve davranışları girmektedir. Bununla birlikte toplumun vergiye bağlı sosyal normları, kişilerin vergilemenin adaletliliği ile ilgili görüşleri de sosyo-psikolojik 
faktörler olarak sayılmaktadır. Mükellefin vergi ile ilgili davranışı çoğu zaman vergiyi algılamasına ve onun adaletli olup olmadığına bağlıdır. Diğer yönden sosyal normların da vergi ile ilgili davranışlar üzerinde etkisi bulunmaktadır (Doerrenberg and Peichl, 2017).

Sosyo-demografik faktörlere olarak mükellefin yaşı, cinsiyeti, medeni durumu, eğitim ve gelir seviyesi sayılmaktadır. Yapılan araştırmalar genellikle bayanların erkeklere göre vergi ahlakı daha yüksek olduğunu (Torgler, 2005; Hug ve Sporri, 2011; OECD, 2013), dindarlık da vergi ahlakını pozitif etkilediği (Torgler, 2005; Daude ve Melguizo, 2010; OECD, 2013), evlilerin de vergi ahlakı daha yüksek olduğu (Torgler, 2003; Torgler 2005; Hug ve Sporri, 2011) açıklanmıştır.

Vergi oranı, denetim sıklığı ve cezaların düzeyleri de vergi ahlakını etkilemektedir. Genellikle vergi ahlakı ile vergi oranı ve denetim sıklığı arasında negatif ilişkinin olduğu savunulmaktadır.

Diğer önemli etkenler grubu vergi ahlakının siyasi belirleyicileridir. Bunlar: devlete güven, hükümete güven, parlamentoya güven, vergi idaresine güven, yargı sistemine güven, doğrudan demokrasi, mali sisteme güven, vergi kanunlarının basit ve anlaşılır olması, kamu mal ve hizmetlerinin kalitesi ve yeterliliğidir.

Mükelleflerin vergi gelirlerin nasıl kullanıldığı ilgili bilgilerin şeffaf olması devlete güveni arttırır (Lillemets, 2010). Cummings v.d. (2005) Kuzey Afrika ve Botsvana ülkeleri için yapılan araştırmalar vergi ahlakını ülkedeki sosyal normlar etkilediğini, ama sosyal normların kaynağı da mükelleflerin devlete olan güveni ve vergi rejimi olduğunu açıklamışlardır. Diğer bir değişle vergi ahlakının oluşmasında ve gelişmesinde devletin mükelleflere adaletli davranışı önemlidir.

Torgler ve Schneider (2007) kamu yönetiminin kalitesi vergi ahlakını nasıl etkilediğini incelemişlerdir ve bu iki kamu yönetiminin kalitesinin vergi ahlakı üzerinde güçlü ve olumlu etkisinin olduğunu açıklamışlardır.

Vergi ahlakının yüksek olmasının koşulları - hepsinden önce iyi bir vergi sistemi, net ve açık kanunlar ve vergi idaresi ile mükellefler arasındaki iyi ilişkilerdir (OECD, 2004; Lillemets, 2010). Devlete güven yargı ve yasal sisteme güveni de bildirir (Torgler, 2007: 154). 
Devlete güveni sarsan en önemli etken yolsuzluktur. Ricjckeghem ve Weder (2002) kamu personelinin ücretlerinin özel sektöre göre yüksek olması yolsuzluğu azaltacağını bildirmiştir. Fakat yolsuzlukla mücadelede ekonomik yönü ele birlikte ahlaki boyutunun da olduğunu dikkate almak gerekir.

\section{Geçiş Ekonomilerinde ve Kırgızistan'da Vergi Sistemi ve Vergi Ahlakı}

Kırgızistan 1991 yılında bağımsızlığını kazanan eski SSCS ülkelerindendir. SSCB döneminde ekonominin hemen hemen hepsi kamu sektörü olduğundan vergi bilinci oluşmamış bir toplumdu. Bu ülkelerin piyasa ekonomisine geçmesinden itibaren piyasa ekonomisine uygun bir vergi sistemini kurmuşlar ve çok kısa bir sürede vergiler uygulanmaya başlamıştır.

Vergi idaresi memurlarının da bu yeni koşullarda çalışma tecrübelerinin yok olması vergi idaresi ile ilgili sorunları ortaya çıkarmıştır. Günümüzde ise ülkenin ekonomik ve sosyal gelişmesi için dış borçlara değil vergi gelirlerinin artırılması en güncel sorunlardan olmaktadır.

Çoğu gelişmekte ve geçiş ekonomilerinde vergi sistemi daha çok dolaylı vergilere dayanmaktadır. Bunun nedeni kayıt dışı ekonomiyi yaygın olması ve vergi idaresinin zayıflığıdır. Kaufmann ve Kaliberda yöntemi ile hesaplandığında geçiş döneminin ilk yıllarında Azerbaycan, Gürcistan ve Ukrayna'da kayıt dışı ekonomisinin seviyesi ilgili olarak GSYiH'ya oranla \% 60.6, \% 62.6\% ve 48.9'a ulaşmıştır (Burov, 2012: 6). Kırgızistan'da günümüzde ise resmi verilere göre \% 25 iken, farklı uzmanlara göre \% 40'a kadar erişebilir (Всеобщая Конфедерация Профсоюзов, 2016: 8).

Tablo 1. İş Yapma Raporuna Göre Geçiş Ekonomilerinde Vergileme Göstergeleri

\begin{tabular}{|l|c|c|c|c|c|}
\hline Ülke & $\begin{array}{c}\text { Ödemeler (1 } \\
\text { yıldaki sayısı) }\end{array}$ & $\begin{array}{c}\text { Zaman (1 yılda } \\
\text { saat) }\end{array}$ & $\begin{array}{c}\text { Vergi Yükü } \\
\text { (karına oranla) }\end{array}$ & $\begin{array}{c}\text { Post filing } \\
\text { index (0-100) }\end{array}$ & $\begin{array}{c}\text { İş Yapma sırası (Doing } \\
\text { Business Rank 2018) }\end{array}$ \\
\hline Ermenistan & 14 & 313 & 18.5 & 49.08 & 87 \\
\hline Azerbaycan & 6 & 195 & 39.8 & 83.79 & 35 \\
\hline Beyazrusya & 7 & 184 & 52.9 & 50 & 96 \\
\hline Estonya & 8 & 50 & 48.7 & 99.38 & 14 \\
\hline Kazakistan & 7 & 178 & 29.2 & 48.85 & 50 \\
\hline Kırgızistan & 51 & 225 & 29 & 37.38 & 151 \\
\hline Rusya & 7 & 168 & 47.6 & 73.14 & 52 \\
\hline Ukrayna & 5 & 327 & 37.8 & 85.95 & 43 \\
\hline Özbekistan & 10 & 181 & 38.3 & 48.39 & 78 \\
\hline
\end{tabular}

Kaynak: İs Yapma Raporunuu Vergileme Göstergeleri / Taxation indicators of Doing Business, 2018. 
İş yapma raporuna göre 1 yılda ödenen ödenekleri en çok olan Kırgızistan olduğu görülmektedir. Bu ise prosedürlerin çok olduğunu ve bu açıdan işlemsel yükün ve harcamaların yüksek olduğunu da söylemek mümkündür. Vergi yükümlülüklerini yerine getirmeye harcanan zaman açısından da en çok olan üçüncü ülkedir. Fakat vergi yükünün karşılaştırmalı olarak düşük olduğunu söyleyebiliriz. Vergi sisteminin etkinliği açısından da (Post filing index (0-100)) puanının en düşük olduğu ülkedir. Vergileme göstergelerine göre sıralamada ise oldukça geride olduğu tabloda gösterilmektedir. Vergi sisteminin Kırgızistan'da etkinliğini arttırma ve adaletliliğini sağlama sorunları acilen çözülmesi gereken bir problem olduğu açıktır.

\section{Veri ve Yöntem}

Kırgızistan'da vatandaşların devlete olan güven ile onların vergi kültürü arasındaki ilişkiyi incelemek amacıyla Dünya Değerler Anketi (DDA - World Values Survey) kullanılmıştır. DDA dünyanın yaklaşık 100 ülkesinde gerçekleştirilmektedir ve dünya halkının \% 90'ını kapsamaktadır. Bu anketin amacı değişen değerlerin ülkelerin sosyal ve siyasi yaşam üzerindeki etkilerini incelemektir. Söz konusu anketin 6.sı 2010-2014 yıllar arasında yapılmıştır. Kırgızistan'da 2011 yılında 1500 kişiye uygulanmıştır. DDA'de vergi ahlakı ile ilgili aşağıdaki ifadeye verilen cevaplar bağımlı değişken olarak kullanılmıştır:

'Imkanım olursa vergi kaçırmak'.

Bu sorunun cevabı 1 ile 10 arasında değişmektedir: 1 - 'Asla haklı değil' ve 10 - ise 'Her zaman haklı' cevabını bildirmektedir. Biz sıralı probıt modelinde bu değişkeni kullanırken 1 - 'Asla haklı değil' ifadesini ' 3 ' olarak kodladık. 7,8,9,10 no'lu ifadeler '0' olarak kodlanmıştır. 4,5,6 no'lu cevaplar '1' olarak, 2 ve 3 no'lu cevaplar '2' olarak kodlanmıştır. Böylece 3 en yüksek vergi ahlakını ve 0 ise en düşük vergi ahlakını bildirmektedir.

Tablo 2. 'Imkanım Olursa Vergi Kaçırmak'Ifadesine Verilen Cevapların Dağııımı

\begin{tabular}{|l|l|l|l|l|l|l|l|l|l|l|}
\hline & \multicolumn{2}{|l}{ 1-Hiç haklı değil ve 10 Her zaman haklı } \\
\hline & 1 & 2 & 3 & 4 & 5 & 6 & 7 & 8 & 9 & 10 \\
\hline Frekansı & 804 & 186 & 131 & 112 & 110 & 30 & 34 & 26 & 25 & 35 \\
\hline Oranı & 53.6 & 12.4 & 8.7 & 7.5 & 7.3 & 2 & 2.2 & 1.7 & 1.6 & 2.3 \\
\hline
\end{tabular}

Bağımsız değişkenler olarak polise güven, mahkemeye güven, hükümete güven, parlamentoya güven, kamu kurumlarına güven, askeri kuvvetlere güveni, insan haklarının korunması, oylama ile ilgili görüşleri, hane halkının gelir sınıfı, medeni durumu ve cinsiyeti kullanılmıştır. 
Tablo 3. Açıklayıcı Değişskenlerin Açıklamaları

\begin{tabular}{|c|c|}
\hline Değişken Adı & Açıklama (Kodlama) \\
\hline Askeri Kuvvetlere Güven & Askeri Kuvvetlere az güvenenler -1 ; diğeri -0 \\
\hline Polise Güven & Polise hiç güvenmeyenler -1 ; diğeri -0 \\
\hline Mahkemeye Güven & Mahkemeye hiç güvenmeyenler -1 ; diğeri -0 \\
\hline Hükümete Güven & Hükümete az güvenenler -1 ; diğeri -0 \\
\hline Parlamentoya Güven & Parlamentoya az güvenenler -1 ; diğeri -0 \\
\hline Kamu Kurumlarına Güven & Kamu Kurumlarına hiç güvenmeyenler -1 ; diğeri -0 \\
\hline İnsan Haklarının Korunması & Ülkemizde insan haklarına saygı duyulmadığını düşünenler - 1; diğeri -0 \\
\hline Ülkede Güvenlik Seviyesi & Ülkedeki durumu oldukça tehlikeli olarak sayanlar - 1; diğeri -0 \\
\hline Seçimler & Oyların satın alınması az sayıda olduğunu düşünenler -1 ; diğeri -0 \\
\hline Ekonomik Sınıfı & Hane halkı eğer çalışma işçi sınıfına girdiğini ifade ederse - 1 ; diğeri -0 \\
\hline Medeni Durumu & $\begin{array}{l}\text { Eğer anketi cevaplayan bekar, dul, ayrılmış veya resmi olarak evli olmayan } \\
\text { birisi ise }-1 \text {; evli ise }-0\end{array}$ \\
\hline Cinsiyet & Eğer erkek ise -1 ; bayan ise -0 \\
\hline
\end{tabular}

Yapılan anketin istatistiksel dağılımına baktığımızda ankete katılanların \%20'si askeri kuvvetlere tamamen güvendiklerini, \%42,8'i bir az güvendiklerini bildirmişlerdir. Polise katılımcıların \%14.6'sı tamamen güvenmekte ve \%40.3'ı bir az güvendiklerini ve \%29'u güveninin az olduğunu söylemişlerdir. Mahkemeye güven diğer devlet kurumlarında en düşük olduğu fark edilmiştir. Katılımcıların sadece \%10.1'i mahkemeye tamamen güvendiklerini, \%39'u bir az güvendiklerini bildirmiştir. Parlamentoya ise katılımcıların \%44'ü bir az güvendiklerini, \%27,5'i güveni az olduğunu, kamu kurumlarına ise katılımcıların \%44.6'sı bir az güvendiklerini, \%30'u güveni az olduğunu, \%14.3'ü hiç güvenmediklerine işaret etmişlerdir.

Ankete katılanların \%17'si ülkede insan haklarının tamamen korunduğu, \%59,8'i bir az korunduğu ve \%18.7'si insan haklarının korunmadığı görüşündedir. Katılımcıların \%22.4'ü seçimlerde oyların çok fazla satın alındığını, \%38'i çok satın alındığını ve \%2 1 az satın alındığını bildirmişlerdir. Bununla birlikte, bu soruyu cevap verenlerin \%10'u cevapsız bırakmışlardır. Ülkede güvenlik konusunda ise, ankete katılanların \%15.5'i ülkede durum tamamen güvenli, \%42'si oldukça güvenli, \%21.8'i yeteri kadar güvenli ve $\% 11.2$ 'si güvensiz olduğunu bildirmişlerdir.

Ankete katılanların \%8.5'i üst sınıfa, \%38'i ortadan daha yüksek sınıfa, \%21.8'i orta sınıfa ve \%29.6'sı işçi sınıfına ait olduklarını işaret etmişlerdir. Katılımcıların \%74'ü evli, \%49'u erkek ve \%1'i bayan olduğu açıklanmıştır. 
Tablo 4. Açıklayıcı Değișkenlerin İstatistiksel Verileri

\begin{tabular}{|c|c|c|c|c|c|c|c|c|c|c|}
\hline \multirow[t]{2}{*}{ Değişken } & \multicolumn{2}{|c|}{$\begin{array}{c}\text { Tamamen } \\
\text { güveniyorum }\end{array}$} & \multicolumn{2}{|c|}{$\begin{array}{c}\text { Bir az } \\
\text { güveniyorum }\end{array}$} & \multicolumn{2}{|c|}{ Güvenim az } & \multicolumn{2}{|c|}{$\begin{array}{c}\text { Hiç } \\
\text { güvenmiyorum }\end{array}$} & \multicolumn{2}{|c|}{ Cevapsız } \\
\hline & Frekansı & Oranı & \begin{tabular}{|c|} 
Frekans \\
1 \\
\end{tabular} & Oranı & Frekansı & Oranı & Frekansı & Oranı & $\begin{array}{c}\text { Frekans } \\
\end{array}$ & Oranı \\
\hline $\begin{array}{l}\text { Askeri } \\
\text { Kuvvetlere } \\
\text { Güven }\end{array}$ & 314 & 20.9 & 642 & 42.8 & 350 & 23.3 & 188 & 12.53 & 6 & 0.4 \\
\hline Polise Güven & 219 & 14.6 & 605 & 40.3 & 435 & 29.0 & 236 & 15.7 & 5 & 0.3 \\
\hline $\begin{array}{l}\text { Mahkemeye } \\
\text { Güven }\end{array}$ & 163 & 10.8 & 589 & 39.2 & 476 & 31.7 & 266 & 17.7 & 6 & 0.4 \\
\hline $\begin{array}{l}\text { Hükümete } \\
\text { Güven }\end{array}$ & 196 & 13.0 & 669 & 44.6 & 413 & 27.5 & 215 & 14.3 & 7 & 0.4 \\
\hline $\begin{array}{l}\text { Parlamentoya } \\
\text { Güven }\end{array}$ & 166 & 11 & 660 & 44 & 450 & 30 & 214 & 14.2 & 10 & 0.6 \\
\hline \multirow[t]{2}{*}{$\begin{array}{l}\text { Kamu } \\
\text { Kurumlarına } \\
\text { Güven } \\
\end{array}$} & 196 & 13 & 669 & 44.6 & 412 & 27.5 & 215 & 14.3 & 7 & 0.4 \\
\hline & \multicolumn{2}{|c|}{ Tamamen korunur } & \multicolumn{2}{|c|}{ Bir az korunur } & \multicolumn{2}{|c|}{ Korunmaz } & \multicolumn{2}{|c|}{ Hiç korunmaz } & \multicolumn{2}{|c|}{ Cevapsız } \\
\hline \multirow[t]{2}{*}{$\begin{array}{l}\text { Insan } \\
\text { Haklarının } \\
\text { Korunması } \\
\end{array}$} & 257 & 17.1 & 897 & 59.8 & 280 & 18.7 & 66 & 4.4 & 0 & 0 \\
\hline & \multicolumn{2}{|c|}{ Tamamen güvenli } & \multicolumn{2}{|c|}{ Oldukça güvenli } & \multicolumn{2}{|c|}{$\begin{array}{l}\text { Yeteri kadar } \\
\text { güvensiz }\end{array}$} & \multicolumn{2}{|c|}{ Tamamen güvensiz } & \multicolumn{2}{|c|}{ Cevapsız } \\
\hline \multirow[t]{2}{*}{$\begin{array}{l}\text { Ülkede } \\
\text { Güvenlik } \\
\text { Seviyesi }\end{array}$} & 222 & 15.5 & 647 & 42.1 & 327 & 21.8 & 169 & 11.2 & 124 & 8 \\
\hline & \multicolumn{2}{|c|}{$\begin{array}{c}\text { Oy çok fazla satın } \\
\text { alınır }\end{array}$} & \multicolumn{2}{|c|}{ Oy çok satın alınır } & \multicolumn{2}{|c|}{ Oy az satın alınır } & \multicolumn{2}{|c|}{ Oy satın alınmaz } & \multicolumn{2}{|c|}{ Cevapsız } \\
\hline \multirow[t]{2}{*}{ Seçimler } & Frekansı & Oranı & Frekansı & Oranı & Frekansı & Oranı & Frekansı & Oranı & Frekansı & Oranı \\
\hline & 351 & 22.4 & 571 & 38.0 & 328 & 21.8 & 99 & 6.6 & 151 & 10 \\
\hline $\begin{array}{l}\text { Ekonomik } \\
\text { SınıfI }\end{array}$ & \multicolumn{2}{|c|}{ Üst sınıf } & \multicolumn{2}{|c|}{$\begin{array}{c}\text { Ortadan yukarı } \\
\text { sınıf }\end{array}$} & \multicolumn{2}{|c|}{ Orta sınıf } & \multicolumn{2}{|c|}{ İşçi Sınıfı } & \multicolumn{2}{|c|}{ Alt sınıf } \\
\hline & 127 & 8.5 & 504 & 33.6 & 377 & 25.1 & 444 & 29.6 & 6 & 0.4 \\
\hline & Evli & & Evli olma & Inlar & & & & & & \\
\hline \multirow[t]{2}{*}{$\begin{array}{l}\text { Medeni } \\
\text { Durumu }\end{array}$} & Frekansı & Oranı & Frekansı & Oranı & & & & & & \\
\hline & 1107 & 74.2 & 393 & 25.8 & & & & & & \\
\hline Cinsiyet & \multicolumn{2}{|c|}{ Erkek } & Bayan & & & & & & & \\
\hline & 736 & 49.1 & 764 & 50.9 & & & & & & \\
\hline
\end{tabular}

(Toplam 1500 anket) 


\section{Empirik Sonuçlar}

Mükelleflerin devlete olan güveninin vergi ahlakı üzerindeki etkisi sıralı probit yöntemi ile incelenmiştir. Bu modelin sonuçları aşağıdaki tabloda (Tablo 5) gösterilmiştir.

Tablo 5. Sıralı Probit Modelinin Sonuçları

\begin{tabular}{|l|c|c|}
\hline \multicolumn{1}{|c|}{ Değişkenler } & Katsayılar & Marjinal Etkileri \\
\hline Askeri Kuvvetlere Güven & -0.0575 & -0.0228 \\
\hline Polise Güven & $0.3293^{* * *}$ & $0.1281^{* * * *}$ \\
\hline Mahkemeye Güven & 0.4732 & 0.0187 \\
\hline Hükümete Güven & 0.0006 & 0.0002 \\
\hline Parlamentoya Güven & -0.0842 & -0.0334 \\
\hline Kamu Kurumlarına Güven & $-0.3129^{* * * *}$ & $-0.1243^{* * *}$ \\
\hline İnsan Haklarının Korunması & $-0.1445^{*}$ & $-0.0575^{*}$ \\
\hline Ülkede Güvenlik Seviyesi & 0.1061 & 0.0420 \\
\hline Seçimler & $-0.1364^{*}$ & $-0.0543^{*}$ \\
\hline Ekonomik Sınıfı & $0.2010^{* * *}$ & $0.0793^{* * *}$ \\
\hline Medeni Durumu & -0.0406 & -0.0161 \\
\hline Cinsiyet & 0.0017 & 0.0007 \\
\hline Cut1 & -1.5613 & \\
\hline Cut2 & -0.6771 & \\
\hline Cut3 & -0.0924 & Log Likelihood $=-1709.28$ \\
\hline LR chi2(12)=34.79 (0.0005) & Pseudo R2 $=0.0101$ & \\
\hline
\end{tabular}

Not: *** ve ***;şaretleri \%10,\%5 ve \%1 seviyesinde anlamlı olduğunu bildirmektedir.

Sıralı probit modelinin sonuçları bize katsayıları vermektedir, fakat bu katsayılar direkt yorumlanamamaktadır. Bu katsayıları yorumlayabilmek için marjinal etkileri hesaplanmıştır. Söz konusu marjinal etkiler Tablo 'de üçüncü sütununda sunulmuştur.

Modelin sonuçlarına göre kamu kurumlarına hiç güvenmeyenlerin diğerlerine göre vergi ahlakı \%12 oranında daha düşüktür. İnsan hakları ülkede korunmadığını düşünenlerin \%5'e düşük olduğu tespit edilmiştir. Seçimlerde oy satın alma az sayıda olduğunu düşünenlerin de vergi ahlakı \%5 oranında daha düşüktür. Bununla birlikte polise hiç güvenmeyenlerin vergi ahlakı ise diğerlerine göre \%12 oranında daha yüksek olduğu açıklanmıştır.

Askeri kuvvetlere güven ve parlamentoya güvenin düşük olması vergi ahlakının da düşük olmasına neden olmaktadır, fakat bu sonuçlar istatistiksel açıdan anlamsızdır. Kendilerini işçi sınıfı olarak sayanların vergi ahlakı ise diğer sınıflara göre yaklaşık \%8 oranında daha yüksek olduğu açıklanmıştır. Bununla birlikte evli olmayanların vergi ahlakı evli olanlara göre daha düşük olduğu görünmektedir, fakat bu katsayılar 
istatistiksel anlamlı değildir. Aynı şekilde erkeklerin de bayanlara göre vergi ahlakı yüksek olduğu tespit edilmiştir, fakat katsayılar istatistiksel anlamlı değildir.

\section{Sonuç ve Öneriler}

İbn Haldun Orta Çağın parlak çok yönlü Arap-i̇slam düşünürlerinden biridir. İbn Haldun olaylara bilimsel yaklaşabilen, onların arkasındaki gerçekleri derin inceleyerek "nedensonuç" ilişkisini kurmaya çalışarak geleceğe yönelik öneriler ve analizler yapan bilim adamıdır. Bunun en ünlü çalışması olan Mukaddime'de sonraki asırlarda çok sayıdaki alanlarda teoriye dönüşen çok sayıda düşünceleri vardır. Bu alanlardan biri de maliyedir. İbn Haldun kişilerin toplum olarak yaşamasının nedenlerini onların kamusal ihtiyaçları olan iç ve dış güvenliği sağlama, ekonomik ve sosyal gelişme ile refaha ulaşma olduğunu eserinde belirtmiştir.

Bunun dışında devletin gelişim sürecini ve bu aşamalarda yöneticilerin davranışlarını inceleyerek bunun nedenlerini de net olarak belirtmiştir. Bunun en önemli nedeni yöneticilerin gelir ve yetkileri arttıkça lükse bağlı kalması, iktidarda uzun süre kalma isteği ve bunların sonucunda asabiyetin kaybolmasıdır. Asabiyet toplumun gücü ve toplumun devlete güvenini ve desteğini bildirmektedir.

Kırgızistan'da geçiş ekonomi sürecinde ciddi ekonomik ve siyasi krizlerden geçmiştir ve günümüzde vergi ahlakını arttırma devletin önemli sorunlarındandır. Çalışmada Kırgızistan'da vergi ahlakının seviyesi ve siyasi faktörlerin vergi ahlakı üzerindeki etkisi 2010 ve 2013 yıllar arasında yapılan Dünya Değerler Anketi (World Values Survey) verilerini kullanarak ve sıralı probit modeli uygulanarak incelenmiştir. Yapılan araştırma sonuçları kamu kurumlarına hiç güvenmeyenlerin vergi ahlakı diğerlere göre \%12 oranında daha düşük, insan hakları ülkede korunmadığını düşünenlerin da vergi ahlakı diğerlerine göre \%5'e daha düşük olduğu tespit edilmiştir.

Bununla birlikte, seçimlerde oy satın almanın az sayıda olduğunu düşünenlerin de vergi ahlakı \%5 oranında düşüktür. Fakat polise hiç güvenmeyenlerin vergi ahlakı ise diğerlerine göre \%12 oranında daha yüksek olduğu açıklanmıştır. Bu paradoks olan sonucun nedeni de ülkede polise olan güven halk arasında genel olarak düşük olduğundan dolayı olabilir.

Kendilerini işçi sınıfı olarak sayanların vergi ahlakı ise diğer sınıflara göre yaklaşık \%8 oranında daha yüksek olduğu açıklanmıştır. Bununla birlikte evli olmayanların vergi ahlakı evli olanlara göre daha düşük olduğu görünmektedir, fakat bu katsayılar 
istatistiksel anlamlı değildir. Aynı şekilde erkeklerin de bayanlara göre vergi ahlakı yüksek olduğu tespit edilmiştir, fakat katsayılar istatistiksel anlamlı değildir.

İbn Haldun en iyi yönetim türü dini kurallara (İslam dininin) göre yönetim olduğunu söylemiştir. Diğer bir değişle, yöneticinin lükse aldanmaması için Allah korkusu ve kimseye zülüm etmeyerek, hakkını yemeden ahiretini düşünerek bu işi gerçekleştirmektir. Bu ilkelerin Kırgızistan'da kamu sektörü memurları ve idarecilerine uygulanması yolsuzluğu minimize ederek mükelleflerin devlete olan güvenini arttıracaktı. Aynı zamanda bu personellerin etkin ve bağımsız çalışabilmeleri için yeterli gelirle/ücretle temin olması gerekir.

\section{Kaynaklar}

Alasfour, F., Samy, M. and Bampton, R. (2016). The determinants of tax morale and tax compliance: Evidence from Jordan. In J. Hasseldine (Ed.) Advances in Taxation Volume 23 (pp. 125-171). Emerald Group Publishing Limited.

Allingham, M. G. and Sandmo, A. (1972). Income tax evasion: A theoretical analysis. Journal of Public Economics, 1, 323-338.

Alm, J., McClelland, G. H. and Schulze, W. D. (1992). Why do people pay taxes? Journal of Public Economics, 48, 21-48.

Burov, V. (2012) Definition of Shadow Economy Scope, Zabaikalsky state University Vestnik Ekonomist (Electronic scientific journal), Number 4, http://vseup.ru

Crequeti, R. and Coppier, R. (2009). Tax revenues, fiscal corruption and "Shame" costs. Economic Modelling, 26(6), 12391244.

Doerrenberg, P. and Peichl, A. (2017). Tax morale and the role of social norms and reciprocity. Evidence from a randomized survey experiment, Discussion Paper No. 17-045, http://ftp.zew.de/pub/zew-docs/dp/dp17045.pdf

Escobari, D. (2005). Tax evasion and the remuneration of tax auditors in a corrupt tax administration [www]. Retrieved from http://ssrn.com/abstract=924066. Accessed on August 15, 2018.

Feld L. P. and Tyran, J.-R. (2002). Tax evasion and voting: An experimental analysis. KYKLOS 55, 197-222.

Frey, B. S. (1999). Economics as a science of human behaviour. Boston/Dordrecht/London: Kluwer Academic Publishers.

Frey, B. S. and Feld, L. P. (2002). Deterrence and morale in taxation: An empirical analysis, CESifo Working Paper No. 760.

Frey, B. S. and Torgler, B. (2004). Taxation and conditional cooperation. Working Paper No. 2004 - 20. Center for Research in Economics, Management and the Arts

Graetz, M. J. and Wilde, L. L. (1985). The economics of tax compliance: Facts and fantasy. national tax journal, 38, 355-363. 
Gupta, R. (2008). Tax evasion and financial repression. Journal of Economics and Business, 60(6), 517535.

Hardin, R. (1998). Trust in government. In Braithwaite, V., Levi M. (Eds.), Trust and Governance (pp. 9-27). New York: Russell Sage Foundation.

Imam, P. ve Jacobs, F. (2007). Effect of corruption on tax revenues in the Middle East [www]. Retrieved from http://www.imf.org/external/pubs/ft/wp/2007/wp07270.pdf

Joulfaian, D. (2009). Bribes and business tax evasion. European Journal of Comparative Economics, 6(2), 227244.

Kendir, H. (2004) Mukkaddime, 287, Ankara: Yeni Şafak Yayınevi.

Long, S. and Swingen, J. (1991). The conduct of tax-evasion experiments: Validation, analytical methods, and experimental realism. In Webley, P., Robben, H., Elffers, H., Hessing, D., Tax Evasion: An Experimental Approach (pp. 128-138). Cambridge: Cambridge University Press.

Lillemets, K., (2010). Tax morale, influencing factors, evaluation opportunities and problems: The case of Estonia, 233-252, http://www.mattimar.ee/publikatsioonid/ majanduspoliitika/2010/12_Kerly_Lilmets.pdf

Luttmer E. F. P. and Singhal, M. (2014). Tax morale. Journal of Economic Perspectives, 28(4), 149-168, http://users.nber.org/ /uttmer/taxmorale.pdf

OECD (2013). Tax and development, http://www.oecd.org/ctp/tax-global/TaxMorale_march 13.pdf

Pommerehne, W. W., Hart, A. and Frey, B. S. (1994). Tax morale, tax evasion and the choice of policy instruments in different political systems. Public Finance, 49 (Supplement), 52-69.

Schmölders, G. (1976). Genel vergi teorisi. (Trans. S. Turhan). İstanbul: IÜ Yay.

Schneider, F., Buehn, A. and Montenegro, C. E. (2010). Shadow economies all over the world: New estimates for 162 countries from 1999 to 2007. http://www.econ.jku.at/members/ Schneider/files/publications/LatestResearch2010/SHADOWECONOMIES_June8_2010_FinalVer sion.pdf

Slemrod, J. (2003). Trust in public Finance. In S. Cnossen, H.-W. Sinn (Ed.), Public Finance and Public Policy in the New Century (pp. 49-88). Cambridge: MIT Press.

Song, Y. and Y.E, Yarbrough. (1978). Tax ethics and tax payer attitudes: A survey. Public Administration Review, 38, 442-457.

Torgler, B. (2001). What do we know about tax morale and tax compliance? International Review of Economics and Business (RISEC) 48, 395-419.

Torgler, B. (2003b). Tax Morale and Institutions. Working Paper No. 2003 - 09. Center for Research in Economics, Management and the Arts

Ümit Hassan (1999) Ibn Haldun'un Metodu ve Siyaset Teorisi, s. 205-208; Orhan Hülagü; Farabi ve Ibn Haldun'da Devlet Düşüncesi, Kırkambar Yay., ìstanbul, s. 69-70.

Yumuk R. (1978) İbn Haldun'da devlet görüşü, Atatürk Üniversitesi Iktisadi ve Idari Bilimler Dergisi, 3(1-2), 230-278.

Всеобщая Конфедерация Профсоюзов (2016) Доклад о неформальной экономике в независимых государствах региона, ее масштабах, позиции и действиях профсоюзов, 18-го ноября, Москва, http://www.vkp.ru/docs/47/675.html (04.09.2018). 